\title{
New principles for a new world
}

[ B OOK REVIEW]

Williams, Michelle \& Satgar, Vishwas (eds) (2013) Marxisms in the 21st century: Crisis, critique and struggle. Johannesburg: Wits University Press. ISBN 978-1-86814-753-3 pbk. Pages vi +298

In a letter written to Arnold Ruge in September of 1843, Karl Marx declared "We do not confront the world in a doctrinaire way with a new principle: 'Here is the truth, kneel down before it!' We develop new principles for the world out of the world's own principles." These lines, affirming Marx's own vision of theory as a necessarily flexible set of tools responsive to social change, are quoted in the preface of a collection of essays published in 1983 to mark the centenary of the great man's death (Matthews, 1983: 9). That volume featured authors like Stuart Hall, Michèle Barrett, Ben Fine, and Göran Therborn, and showcased Marxism's ongoing relevance with regard to late twentieth century issues: class, gender, shifts in capitalist production, ideology and aesthetics.

Marxism in the $2 \mathbf{2}^{\text {st }}$ century is conceived with a similar intention. Pointing to the "flowering" of creative Marxist thinking taking place in other parts of the world, in response to challenges peculiar to our own era, this book sets out to contribute to the global conversation. Presenting work from and about the South/African region, it also aims to provide a counterpoint to, and criticism of, the protracted vanguardism and orthodoxies of Party communism that constitute the official Marxism within South African alliance politics.

\section{Thembisa Waetjen}

University of Johannesburg Johannesburg 
Unsettling South African politics from its parochial and nationalist gaze is indeed an urgent undertaking. We sit within a global context defined by predatory formations of financialised capitalist relations and resource plundering that since the 1980s has eroded the social and ushered in what Saskia Sassen recently described as a newly brutal, world-scale "logics of expulsion" (Sassen, 2016: 11). Manifestations of these trends in Africa, and their regional production through state-aided neoliberal policies, have compounded rather than ameliorated the socio-economic inequalities produced through racial capitalism under both colonialism and apartheid. In South Africa - as in Europe, the USA and elsewhere - the devastating social effects of these trends are increasingly expressed in reactionary and divisive populist voices and through mainstream analyses that fail to specify, historicize - or explain - current crises.

The essays in this volume present a range of concerns and approaches. They commonly reflect the necessity of transnational civic strategies and solidarities, even if they do not necessarily agree on the form political action should take. A brief summary of the chapters, which are clustered in three sections, will indicate what is on offer for different readers.

The chapters that make up the first section demonstrate Marxism as an evolving tradition. The authors revisit and revise key ideas within Marxist thought to newly theorize the current state of global capitalism and our prospects for collective action, contextualizing their respective discussions within intellectual and historical genealogies. Michelle Williams shows that debates about Marxism's relationship to democracy, long held hostage by cold war thinking which pitted representative democracy against its communist vanguard "other", are shifting through experimentation in the Global South. Movements in Brazil and India demonstrate the transformative possibilities of direct and participatory democracy, where "ordinary citizens are directly involved in the activities of political (and economic) governance" ( $p$ 26). Michael Burawoy reconstructs Polanyi's theory of marketization to present a new rubric both for periodising Marxism in relation to the changing nature and threat of global capitalism. He outlines three historical "waves" of commodification (of labour, money and nature) and countermovement, arguing that our current third wave heralds global crises in all three marketised "fictions". In the third essay, Vishwas Satgar considers the power of a "transnationalized" neo-Gramscian perspective for thinking through class politics and neoliberalisation in South Africa. He develops the idea of "passive revolution" as a way of understanding how, from 1996, "the rule of capital eclipsed a working-class-led hegemonic project for a democratic corporatist state" ( $p$ 77).

A second section looks to the influence and continuing relevance of Marxism within left politics. Two of these read as literature reviews around core social issues. Devan Pillay provides an overview of the debates about environmental degradation and its links 
to the relations of fossil fuel capitalist production. John Foster, Brett Clark and others (e.g. Foster, Clark \& York, 2010) have argued how Marx's own analysis identified the key contradiction of "metabolic rift", the basis for a flourishing activism informed by Marxist ecology. Jacqueline Cock's and Meg Luxton's reappraisal of the "unhappy marriage" of Marxism and Feminism summarizes the contexts and histories of various schools of thought that sought to bring class and gender into shared frame of political action. It draws attention to areas both of failure and of progress in efforts to build an inclusive platform for a social feminist politics, and reasserts the value of continued struggle towards this ideal. In some ways the outlier in this section, Ahmed Veriava's essay is a deeply philosophical intervention. It argues for the continued importance of "doing critique" as a form of political action by tracing an ontological line from Marx to Foucault - with a brief consideration of Biko - against a tradition of Kantian rationalism.

While essays in the first two sections speak with some reference to African contexts, Marxist histories and applications on the continent are more directly addressed in the third section of this book. These essays, which reflect on "crises of Marxism" and "possibilities for the future" also more directly speak to each other. The geographical focus here begins broadly and narrows with each contribution. Daryl Glaser presents "seven theses about Africa's Marxist regimes" to identify and assess some broad patterns and processes shaping experiences of Marxist-Leninist governance in post-colonial nations as diverse as Mali, Angola, Benin, Ethiopia, Madagascar, Burkina Faso, Mozambique, and others. He looks to key elements within the ascendency and demise of these episodes that contributed to a story of overwhelming failure ("disastrous by virtually any defensible metric", p 168). John Saul similarly evaluates national experiences of socialism, focusing on the two "eminently discussable cases" of Mozambique and Tanzania. He asserts that both the weaknesses and strengths of these cases can offer lessons, but that these were lost to South Africa in its blanket denouncement of regional socialism and its blind submission to global capitalism during its own moment of political liberation. In his assessment, the lessons of socialism in the region can yet "tell us more ... about what might need to be done to make socialism real than they do about the irrelevance of the intention [to craft a socialist society]" ( $p$ 200). Saul looks, for example, to the direction FRELIMO was moving prior to the assassination of Eduardo Modlane, the "qualitative transformation" from social solidarities rooted in antagonism to colonialism towards a positive embrace of socialism as an achievable and desired outcome in its own right.

Modlane claimed that, within this emerging ethos, "it would now be 'impossible to create a capitalist Mozambique ... [1]t would be ridiculous ... for the people to struggle, to destroy the economic structure of the enemy and then reconstituted in such a way as to serve the enemy." ( $p$ 209) Yet in South Africa, the enemy's edifice was embraced. Notwithstanding the failures of its northeastern neighbours, can South 
Africa's experience of neoliberal capitalism be called a "success"? With Williams, Saul sees promise in a "counter-hegemonic politics" as illustrated by participatory politics in Kerela. Meanwhile, the ANC/SACP block has continually worked for a "hegemonic generative politics".

In the next chapter, Patrick Bond, Ashwin Desai and Trevor Ngwane adapt Trotsky's concept of "uneven and combined development" to describe Marxism in South Africa's political terrain of "townships, shack-dweller communities, flat-dweller communities and dorpies" ( $p$ 228), where residents claim a diverse range of critical relationships to employment status, government service, and social power. This, among other conditions, has produced a "movement sector" they characterize as "extraordinarily militant in its actions and profoundly moderate in its politics" ( $p$ 231). They depart from Williams' optimistic view of participation, citing Sinwell's observation (2009) that community activism has failed adequately to address structural relations of power. Thus, unlike Saul, they conceive the primary challenge to be "creat[ing] from this [local] unevenness a hegemonic formation" ( $p$ 222), with intellectual leadership that will graft its local energies to the anti-capitalist struggles of the global left.

While Bond et al consider the picture "from below", the final essay by Mazibuko Jara addresses the crisis of Marxism generated through the alliance politics of the ANC state. He argues that the use of Marxist discourses in the current juncture represents an "Afro-neoliberal project" that attempts to reconcile the working class and poor to deracialised and transnational capitalism. The ANC has not only failed to achieve its stated nation-building aims, but has pursued policies that have

"Opened the door to the reproduction of apartheid racial categories and regressive forms of nationalism including the return of ethnic identity, white supremacist arrogance, regressive racial polarization, narrow black elite solidarity and African chauvinism, particularly in relation to the so-called Indian and coloured racial 'minorities'”. (p 261)

Jara explores two local case studies that illustrate these dynamics: racialised struggles over housing in the Western Cape; and government legislative efforts to "retribalize" society in the former homelands, where residents are subjected to customary authority against the grain of democratic and national processes.

The ANC's Marxism, says Jara, is incapable of generating the transformative political and economic project that South Africa requires and instead has generated conditions for a "narrow and limited" Afro-neoliberalism, which seeks to align elite interests with race populism, eschewing any recognition of structurally produced inequalities. We 
are effectively witnessing a retreat from nation-building and a reversion to a familiar essentialist and subjectivist identity politics.

This last observation provides a gateway for raising a critical question about this volume as a whole. Directed towards the task of nudging twentieth century Marxists towards present social realities and new analyses, does this book extend a compelling invitation to new generations of thinkers and activists who are either unfamiliar with Marxism or who actively sideline or reject it as a distraction and deception of the white left? The sudden rise of university students, as the most visible and consequential sector of radical activism, has taken most of us by surprise. Only a little more than a year after this book's publication, we have seen a deeply subjectivist, race-based challenge to class analysis issuing from some quarters of the \#RhodesMustFall / \#FeesMustFall student movement. To be sure, a critique of inequality is at the centre of concerns here, but the poverty of analysis - which is notably lacking in explanatory power, and relies instead on the criticism of ongoing racist attitudes and privileged status - reflects much of what Jara laments.

How can Marxism more directly speak to, and inspire, the thinking and political activism of young people who - disillusioned with the pace, limitations and outright failures of twenty years of promised transformation - are demonstrating their resolve to be a new vanguard of reform?

\section{References}

Foster, J, Clark, B \& York, R (2010) The ecological rift: Capitalism's war on the earth. New York: Monthly Review Press.

Matthews, B (ed) (1983) Marx: 100 years on. London: Lawrence \& Wishart.

Sassen, S (2014) Expulsions: Brutality and complexity in the global economy.

Cambridge: Harvard University Press.

Sinwell, L (2009) Participation as popular agency. Unpublished PhD Thesis, University of the Witwatersrand, Johannesburg. 